\title{
$N$-(1-Acylaminoalkyl)amidinium salts derived from DBU or related bases as reactive intermediates in $\alpha$-amidoalkylation reactions
}

\author{
Agnieszka Październiok-Holewa, Jakub Adamek, Katarzyna Zielińska, \\ Katarzyna Piernikarczyk, and Roman Mazurkiewicz ${ }^{*}$ \\ Department of Organic and Bioorganic Chemistry and Biotechnology, Silesian University of \\ Technology, Krzywoustego 4, PL 44-100 Gliwice, Poland \\ E-mail: Roman.Mazurkiewicz@polsl.pl
}

Dedicated to Prof. Pawel Kafarski in honor of his life time achievements in chemistry

\begin{abstract}
1-(N-Acylamino)alkyltriphenylphosphonium salts 4, when treated with DBU, DBN or TBD in $\mathrm{CD}_{3} \mathrm{CN}$ or $\mathrm{MeCN}$, were transformed immediately into the corresponding 1- $(N-$ acylamino)alkylamidinium or guanidinium salts 5. Salts 5 with a proton at the $\alpha$-position underwent slow transformation to the corresponding enamides $\mathbf{6}$. $1-(N-$ Acylamino)alkyltriphenylphosphonium salts $\mathbf{4}$, amidinium or guanidinium salts $\mathbf{5}$, as well as enamides 6 reacted readily with $\beta$-dicarbonyl compounds in the presence of corresponding base under microwave irradiation at $60{ }^{\circ} \mathrm{C}$ to give the expected product of $\alpha$-amidoalkylation of the enolate anion. The role of 1-( $N$-acylamino)alkylamidinium or guanidinium salts $\mathbf{5}$ as reactive intermediates in $\alpha$-amidoalkylation with 1 - $(N$-acylamino)alkyltriphenylphosphonium salts is discussed.
\end{abstract}

Keywords: 1-( $N$-Acylamino)alkyltriphenylphosphonium salts, 1-( $N$-acylamino)alkylamidinium salts, $\alpha$-amidoalkylation, $N$-acylimines, enamides, non-nucleophilic bases

\section{Introduction}

$N$-Acylimines $\mathbf{2}$ and $\mathrm{N}$-acyliminium cations $\mathbf{3}$ are highly reactive short-lived intermediates of many important transformations in organic synthesis, notably, the $\alpha$-amidoalkylation of a wide variety of $\mathrm{O}, \mathrm{N}, \mathrm{S}, \mathrm{P}$ and $\mathrm{C}$-nucleophiles. ${ }^{1-5}$ Most frequently, $\mathrm{N}$-acylimines or $\mathrm{N}$-acyliminium cations are generated in situ from $\alpha$-substituted $N$-alkylamides with a nucleofugal leaving group $\mathrm{Z}$ at the $\alpha$-position by a base-catalysed $\beta$-elimination of $\mathrm{HZ}$ (to give the $N$-acylimine) or by an acid-catalysed loss of the $\mathrm{Z}$ group (to give the $N$-acyliminium cation) (Scheme 1). ${ }^{1,6-8}$ 


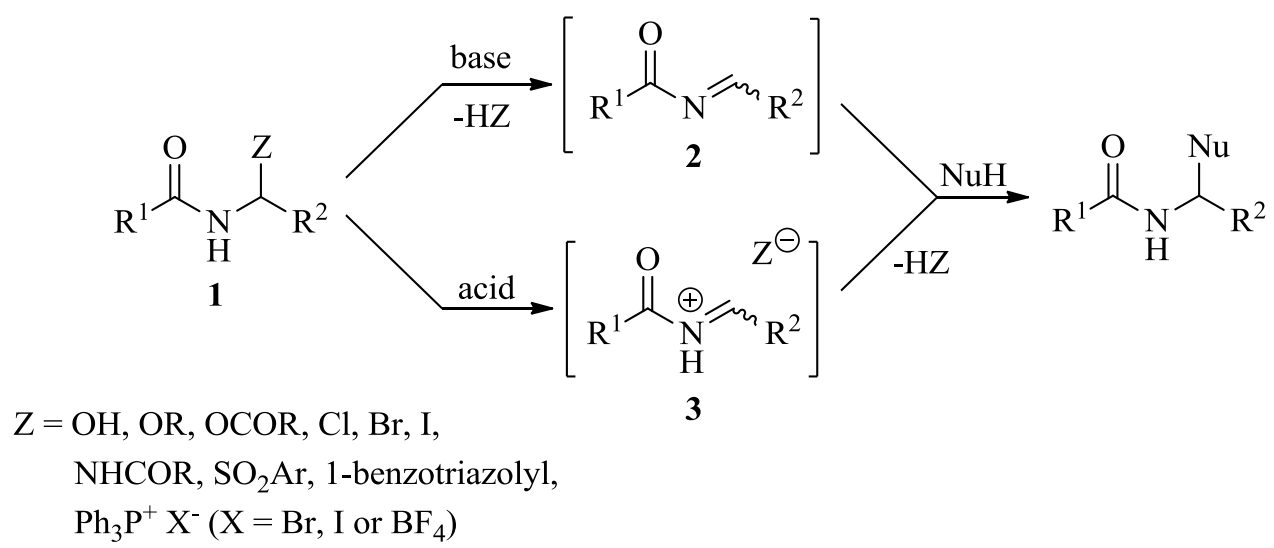

\section{Scheme 1}

Numerous $\alpha$-amidoalkylating reagents of general structure 1 have been used to generate $N$ acylimines $\mathbf{2}$, or their protonated form $\mathbf{3}$, where $\mathrm{Z}$ represents usually $\mathrm{OH}, \mathrm{OR}, \mathrm{OCOR}, \mathrm{Cl}, \mathrm{Br}, \mathrm{I}$, NHCOR, $\mathrm{SO}_{2} \mathrm{Ar}$ or 1-benzotriazolyl. ${ }^{1,6,9-12}$ Recently, we have described three independent, efficient methods for the synthesis of 1-(N-acylamino)alkyltriphenylphosphonium salts $4(\mathbf{1}=\mathbf{4}$ if $\mathrm{Z}=\mathrm{Ph}_{3} \mathrm{P}^{+} \mathrm{X}^{-}$and $\mathrm{X}=\mathrm{Br}$, I or $\left.\mathrm{BF}_{4}\right)$, including hitherto unknown 1-substituted-1- $(N$ acylamino)alkyltriphenylphosphonium salts $\left(\mathrm{R}^{2} \neq \mathrm{H}\right) \cdot{ }^{13-19}$ We have also demonstrated that phosphonium salts $\mathbf{4}$ are effective and convenient amidoalkylating agents when activated with organic bases (DBU or $\left.i-\operatorname{Pr}_{2} \mathrm{EtN}\right){ }^{15,20,21}$

The particularly straightforward and useful method for the synthesis of phosphonium salts 4 consists in the electrochemical decarboxylative $\alpha$-alkoxylation (usually $\alpha$-methoxylation) of easily accessible $N$-acyl- $\alpha$-amino acids (well known as the Hofer-Moest reaction) ${ }^{22-34}$ followed by the displacement of the $\alpha$-alkoxy group with triphenylphosphonium group by treatment with triphenylphosphine tetrafluoroborate (Scheme 2). ${ }^{16,19}$

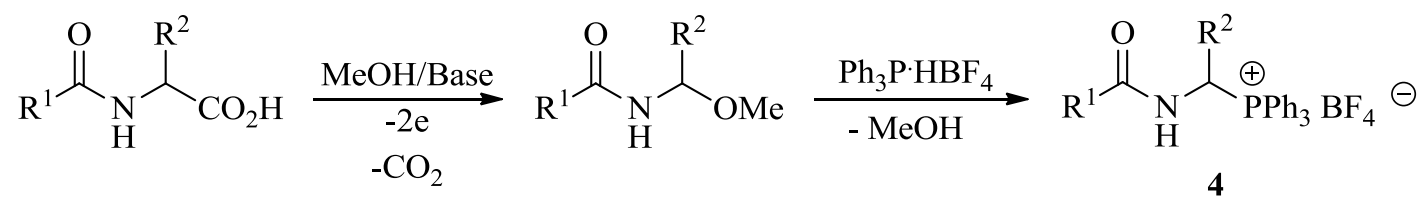

\section{Scheme 2}

The availability of a large variety of natural $\alpha$-amino acids (both proteinogenic and unproteinogenic ones), as well as an infinite number of unnatural $\alpha$-amino acids provides potential access to a wide variety of structurally diverse 1- $(N$ acylamino)alkyltriphenylphosphonium salts 4. This markedly broadens the scope for the synthetic application of the amidoalkylating properties of these compounds.

Phosphonium salts $\mathbf{4}$ react smoothly with relatively acidic heteroatom nucleophiles, such as imides, mercaptanes or phenols in the presence of $i$ - $\operatorname{Pr}_{2} \operatorname{EtN}$ (Hünig's base), whereas the 
amidoalkylation of carbon nucleophiles, e.g., malonic or acetylacetic acid derivatives, requires the use of stronger bases, like DBU. ${ }^{15,21}$ In the present communication we report our investigations of some unexpected reactions of phosphonium salts 4 with DBU and related bases (e.g., DBN or TBD), which generate the corresponding $N$-(1-acylaminoalkyl)amidinium or $N$-(1acylaminoalkyl)guanidinium salts (so far unknown). The role of these salts as intermediates in $\alpha$ amidoalkylation with phosphonium salts $\mathbf{4}$ will be also discussed.

\section{Results and Discussion}

1-(N-Acylaminoalkyl)triphenylphosphonium salts 4a-j (Table 1) reacted immediately with DBU, DBN or TBD in $\mathrm{MeCN}$ or $\mathrm{CD}_{3} \mathrm{CN}$, which allowed the reaction to be monitored directly by ${ }^{1} \mathrm{H}$ NMR spectroscopy. Upon treatment with DBU, DBN or TBD, the signal of the $\alpha$-methylene or $\alpha$-methine group in the ${ }^{1} \mathrm{H}$ NMR spectrum of the phosphonium salts at 5.08-6.96 ppm was immediately replaced by a signal in the range of 5.01-6.94 ppm, without the characteristic $J_{\mathrm{P}-\mathrm{H}}$ coupling constant (3.3-7.5 Hz) (Figure 1). ${ }^{13} \mathrm{C}$ NMR spectra of the reaction mixture also gave evidence of the disappearance of the initial phosphonium salt and the formation of free triphenylphosphine and another compound. In most cases, evaporation of the solvent and washing out of triphenylphosphine and other impurities with toluene gave the main reaction product, as a thick oil, in good purity and yield (Table 1). Attempts to obtain these compounds in a crystalline form failed.

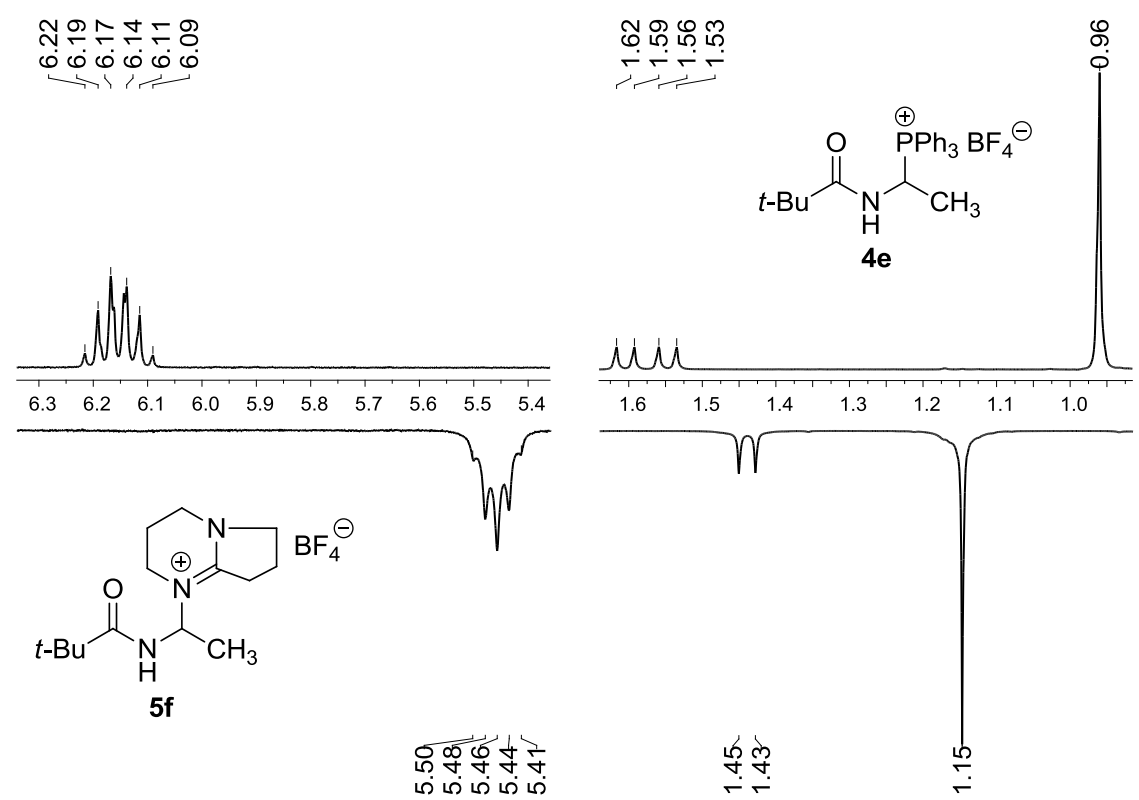

Figure 1. The position and multiplicity of the characteristic signals of phosphonium salt $4 \mathbf{e}[6.15$ $\left.(1 \mathrm{H}, \mathrm{m}, \mathrm{CH}), 1.58\left(3 \mathrm{H}, \mathrm{dd}, J_{l}=17.3 \mathrm{~Hz}, J_{2}=7.4 \mathrm{~Hz}, \mathrm{CH}_{3}\right), 0.96(9 \mathrm{H}, \mathrm{s}, t-\mathrm{Bu})\right]$ and amidinium salt $5 \mathbf{f}\left[5.46\left(1 \mathrm{H}, \mathrm{dq}, J_{1}=6.9 \mathrm{~Hz}, J_{2}=6.6 \mathrm{~Hz}, \mathrm{CH}\right), 1.44\left(3 \mathrm{H}, \mathrm{d}, J=6.9 \mathrm{~Hz}, \mathrm{CH}_{3}\right), 1.15(9 \mathrm{H}, \mathrm{s}, t\right.$ $\mathrm{Bu})$ ]; $\mathrm{CD}_{3} \mathrm{CN}, 300 \mathrm{MHz}$. 


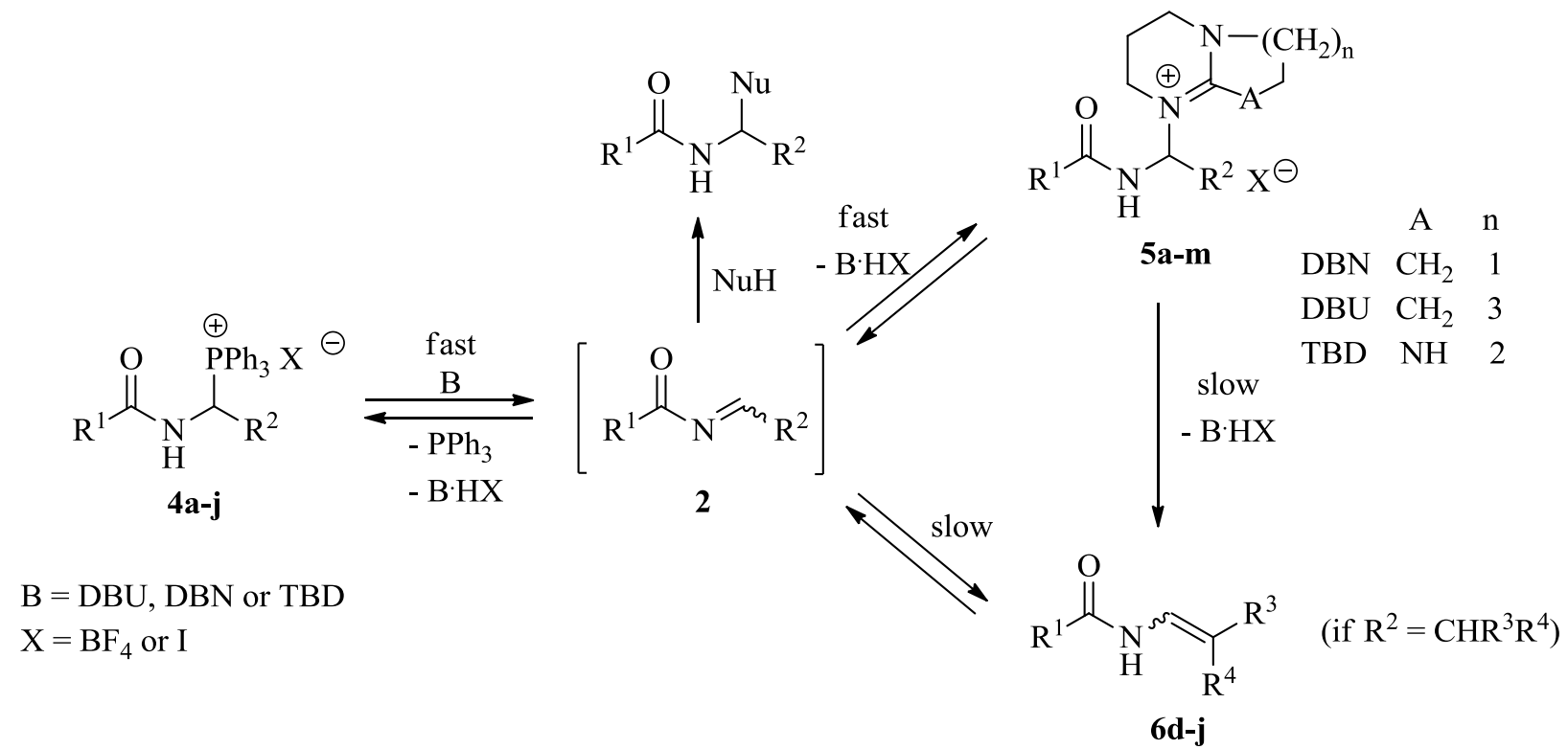

\section{Scheme 3}

High-resolution mass spectroscopy with ESI-ionisation of the obtained compounds revealed that, in all of the cases, the molecular formula of the molecular ion matched the cation of the corresponding $N$-(1-acylaminoalkyl)amidinium or $N$-(1-acylaminoalkyl)guanidinium salts 5 formed by amidoalkylation of DBU, DBN or TBD (Scheme 3, Table 1). Further spectroscopic investigations of the salts 5a-m confirmed their structures. In ${ }^{13} \mathrm{C}$ NMR spectra the characteristic signals of $\mathrm{C}_{\alpha}$ carbons $(60.3-67.8 \mathrm{ppm}), \mathrm{C}=\mathrm{O}$ groups $(156.4-181.5 \mathrm{ppm})$ and $\mathrm{C}=\mathrm{N}^{+}$groups (152.1 - $168.4 \mathrm{ppm})$, as well as signals of the other carbons were present (see Experimental). In IR spectra the $v_{\mathrm{NH}}, v_{\mathrm{C}=\mathrm{O}}$ and $v_{\mathrm{C}=\mathrm{N}}$ bonds were observed at $3355-3394 \mathrm{~cm}^{-1}, 1625-1723 \mathrm{~cm}^{-1}$ and $1598-1660 \mathrm{~cm}^{-1}$, respectively. It is surprising that DBU and related bases, which are considered to be sterically hindered and, therefore, "non-nucleophilic," 35 react so easily with phosphonium salts 4. However, recently, several reports of the reaction of DBU with strong electrophilic agents have been published. ${ }^{36-38}$

Table 1. Transformation of phosphonium salts $\mathbf{4}$ into amidinium or guanidinium salts 5

\begin{tabular}{|c|c|c|c|c|c|c|c|c|c|c|c|}
\hline \multicolumn{4}{|c|}{ Phosphonium salt 4} & \multirow{2}{*}{\multicolumn{2}{|c|}{$\begin{array}{c}\text { Molar } \\
\text { ratio } \\
\text { of } \\
\text { salt } 4 \\
\text { : base } \\
\end{array}$}} & \multicolumn{3}{|c|}{ Salt 5} & \multicolumn{3}{|c|}{$\operatorname{HR}-M S(m / z)^{\mathrm{a}}$} \\
\hline & $\mathrm{R}^{1}$ & $\mathrm{R}^{2}$ & $X$ & & & & $\begin{array}{c}\text { Yield }^{\mathrm{b}} \\
(\%)\end{array}$ & $\begin{array}{c}\text { Yield }^{\mathrm{c}} \\
(\%)\end{array}$ & $\begin{array}{l}\text { For the } \\
\text { formula }^{\mathrm{d}}\end{array}$ & Calcd & Found \\
\hline $4 a$ & $\mathrm{Ph}$ & $\mathrm{H}$ & $\mathrm{BF}_{4}$ & DBU & $1: 1$ & $5 \mathbf{a}$ & 99 & 82 & $\mathrm{C}_{17} \mathrm{H}_{24} \mathrm{~N}_{3} \mathrm{O}$ & 286.1913 & 286.1908 \\
\hline $4 b$ & $t-\mathrm{Bu}$ & $\mathrm{H}$ & $\mathrm{BF}_{4}$ & $\mathrm{DBU}$ & $1: 1$ & $5 b$ & 99 & 93 & $\mathrm{C}_{15} \mathrm{H}_{28} \mathrm{~N}_{3} \mathrm{O}$ & 266.2227 & 266.2230 \\
\hline $4 c$ & $\mathrm{Me}$ & $\mathrm{Ph}$ & $\mathrm{BF}_{4}$ & DBU & $1: 1.25$ & $5 c$ & 75 & $-{ }^{e}$ & $\mathrm{C}_{18} \mathrm{H}_{26} \mathrm{~N}_{3} \mathrm{O}$ & 300.2070 & 300.2059 \\
\hline
\end{tabular}


Table 1. Continued

\begin{tabular}{|c|c|c|c|c|c|c|c|c|c|c|c|}
\hline \multicolumn{4}{|c|}{ Phosphonium salt 4} & \multirow{2}{*}{\multicolumn{2}{|c|}{$\begin{array}{cc}\text { Molar } \\
\text { Batio }\end{array} \quad \begin{array}{c}\text { of } \\
\text { salt } 4 \\
\text { : base }\end{array}$}} & \multicolumn{3}{|c|}{ Salt 5} & \multicolumn{3}{|c|}{ HR-MS $(m / z)^{\mathrm{a}}$} \\
\hline & $\mathrm{R}^{1}$ & $\mathrm{R}^{2}$ & $X$ & & & & $\begin{array}{c}\text { Yield }^{\mathrm{b}} \\
(\%)\end{array}$ & $\begin{array}{c}\text { Yield }^{\mathrm{c}} \\
(\%)\end{array}$ & $\begin{array}{l}\text { For the } \\
\text { formula }^{\mathrm{d}}\end{array}$ & Calcd & Found \\
\hline $4 c$ & $\mathrm{Me}$ & $\mathrm{Ph}$ & $\mathrm{BF}_{4}$ & DBN & $1: 1$ & $5 d$ & 99 & $-\mathrm{e}$ & $\mathrm{C}_{16} \mathrm{H}_{22} \mathrm{~N}_{3} \mathrm{O}$ & 272.1763 & 272.1754 \\
\hline $4 d$ & $t-\mathrm{Bu}$ & $\mathrm{Me}$ & I & $\mathrm{DBU}$ & $1: 1.25$ & $5 e$ & 66 & 75 & $\mathrm{C}_{16} \mathrm{H}_{30} \mathrm{~N}_{3} \mathrm{O}$ & 280.2383 & 280.2385 \\
\hline $4 e$ & $t-\mathrm{Bu}$ & $\mathrm{Me}$ & $\mathrm{BF}_{4}$ & $\mathrm{DBN}$ & $1: 1.25$ & $5 f$ & 96 & 93 & $\mathrm{C}_{14} \mathrm{H}_{26} \mathrm{~N}_{3} \mathrm{O}$ & 252.2070 & 252.2070 \\
\hline $4 e$ & $t-\mathrm{Bu}$ & $\mathrm{Me}$ & $\mathrm{BF}_{4}$ & TBD & $1: 1.25$ & $5 g$ & 90 & 97 & $\mathrm{C}_{14} \mathrm{H}_{27} \mathrm{~N}_{4} \mathrm{O}$ & 267.2179 & 267.2189 \\
\hline $4 f$ & $\mathrm{PhCH}_{2} \mathrm{O}$ & $\mathrm{Me}$ & $\mathrm{BF}_{4}$ & DBU & $1: 1.25$ & $5 \mathbf{h}$ & 53 & $-^{e}$ & $\mathrm{C}_{19} \mathrm{H}_{28} \mathrm{~N}_{3} \mathrm{O}_{2}$ & 330.2176 & 330.2182 \\
\hline $4 \mathbf{f}$ & $\mathrm{PhCH}_{2} \mathrm{O}$ & $\mathrm{Me}$ & $\mathrm{BF}_{4}$ & $\mathrm{DBN}$ & $1: 1.25$ & $5 \mathbf{i}$ & 98 & 87 & $\mathrm{C}_{17} \mathrm{H}_{24} \mathrm{~N}_{3} \mathrm{O}_{2}$ & 302.1863 & 302.1868 \\
\hline $4 f$ & $\mathrm{PhCH}_{2} \mathrm{O}$ & $\mathrm{Me}$ & $\mathrm{BF}_{4}$ & TBD & $1: 1$ & $5 \mathbf{j}$ & 99 & 97 & $\mathrm{C}_{17} \mathrm{H}_{25} \mathrm{~N}_{4} \mathrm{O}_{2}$ & 317.1972 & 317.1967 \\
\hline $4 g$ & $\mathrm{PhCH}_{2} \mathrm{O}$ & $i-\operatorname{Pr}$ & $\mathrm{BF}_{4}$ & $\mathrm{DBU}$ & $1: 1$ & $5 \mathbf{k}$ & 53 & $-^{\mathrm{e}}$ & $\mathrm{C}_{21} \mathrm{H}_{32} \mathrm{~N}_{3} \mathrm{O}_{2}$ & 358.2489 & 358.2504 \\
\hline $4 h$ & $\mathrm{PhCH}_{2} \mathrm{O}$ & $\mathrm{CH}_{2} \mathrm{O}-t-\mathrm{Bu}$ & $\mathrm{BF}_{4}$ & $\mathrm{DBU}$ & $1: 1$ & 51 & 79 & 80 & $\mathrm{C}_{23} \mathrm{H}_{36} \mathrm{~N}_{3} \mathrm{O}_{3}$ & 402.2751 & 402.2755 \\
\hline $4 \mathbf{i}$ & $t-\mathrm{Bu}$ & $\mathrm{CH}_{2} \mathrm{OMe}$ & I & DBU & $1: 1.25$ & $5 \mathrm{~m}$ & 97 & 77 & $\mathrm{C}_{17} \mathrm{H}_{32} \mathrm{~N}_{3} \mathrm{O}_{2}$ & 310.2489 & 310.2491 \\
\hline
\end{tabular}

${ }^{a}$ ESI, only in the case of compound $\mathbf{5 d}$ a FD ionisation was applied. ${ }^{\mathrm{b}}$ Yield estimated by ${ }^{1} \mathrm{H}$ NMR spectroscopy of reaction mixtures based on a ratio of the selected signal intensity of salt $\mathbf{5}$ (usually the $\mathrm{C}_{\alpha} \mathrm{H}$ signal) to the total intensity of aromatic protons signals. ${ }^{\mathrm{c}}$ Isolated yield. ${ }^{\mathrm{d}}$ The formula of the corresponding amidinium or guanidinium cation. ${ }^{\mathrm{e}}$ Attempts to isolate amidinium salt 5 failed; for HRMS and spectral analyses the salt was prepared in situ.

Properties of $\alpha$-substituted amidinium or guanidinium salts with a proton at the $\beta$-position (5e-m, $\mathrm{R}^{2}=\mathrm{CHR}^{3} \mathrm{R}^{4}$ ) differ in some respects from the properties of $\alpha$-substituted salts without such a proton (e.g., 5c-d) or $\alpha$-unsubstituted amidinium salts $\mathbf{5 a - b}\left(\mathrm{R}^{2}=\mathrm{H}\right)$. In contrast to the salts 5a-d, $\alpha$-substituted salts with a proton at the $\beta$-position underwent slow transformation in the reaction mixture to the corresponding enamides $\mathbf{6 d - j}$. E.g. in the reaction of 1-(Nbenzyloxycarbonylamino)ethyltriphenylphosphonium tetrafluoroborate $\mathbf{4 f}$ with $\mathrm{DBU}$ in $\mathrm{CD}_{3} \mathrm{CN}$ at $20^{\circ} \mathrm{C}$ at a 1:1.25 molar ratio of $\mathbf{4 f}$ to $\mathrm{DBU}$, the $\mathbf{5 h}: \mathbf{6 f}$ molar ratio was 50:50 after eight minutes, 28:72 after twenty minutes, and after 3 hours the 5h:6f molar ratio levelled out at a value of 17:83. The reaction mixture contained also a trace amount of another compound, which was finally identified as dimer 7 (see below). 
Table 2. Transformation of phosphonium salts 4 to enamides 6

\begin{tabular}{|c|c|c|c|c|c|c|c|c|c|c|c|}
\hline & \multicolumn{3}{|c|}{ Phosphonium salt 4} & \multicolumn{3}{|c|}{ Reaction conditions } & \multicolumn{5}{|c|}{ Enamide 6} \\
\hline & $\mathrm{R}^{1}$ & $\mathrm{R}^{2}$ & $\mathrm{X}$ & $\begin{array}{c}\text { Molar ratio } \\
\text { of salt } 4 \text { : } \\
\text { base }\end{array}$ & $\begin{array}{c}\text { Temp. } \\
\left({ }^{\circ} \mathrm{C}\right)\end{array}$ & Time & & $\mathrm{R}^{3}$ & $\mathrm{R}^{4}$ & $\begin{array}{c}\text { Yield }^{\mathrm{a}} \\
(\%)\end{array}$ & $\mathrm{Mp}\left({ }^{\circ} \mathrm{C}\right)$ \\
\hline 4d & $t-\mathrm{Bu}$ & $\mathrm{Me}$ & I & $1: 1.25$ & 20 & $6 \mathrm{~d}$ & $6 d$ & $\mathrm{H}$ & $\mathrm{H}$ & 48 & $92.0-93.0^{\mathrm{b}}$ \\
\hline $4 f$ & $\mathrm{PhCH}_{2} \mathrm{O}$ & $\mathrm{Me}$ & $\mathrm{BF}_{4}$ & $1: 1.25$ & 20 & $3 \mathrm{~h}$ & $6 f$ & $\mathrm{H}$ & $\mathrm{H}$ & $17^{\mathrm{c}}$ & $36.0-38.0^{\mathrm{d}}$ \\
\hline $4 \mathrm{~g}$ & $\mathrm{PhCH}_{2} \mathrm{O}$ & $i-\operatorname{Pr}$ & $\mathrm{BF}_{4}$ & $1: 1.25$ & 20 & $3 \mathrm{~h}$ & $6 \mathrm{~g}$ & $\mathrm{CH}_{3}$ & $\mathrm{CH}_{3}$ & 62 & $40.0^{\mathrm{e}}$ \\
\hline $4 h$ & $\mathrm{PhCH}_{2} \mathrm{O}$ & $\begin{array}{c}\mathrm{CH}_{2} \mathrm{O}- \\
t-\mathrm{Bu}\end{array}$ & $\mathrm{BF}_{4}$ & $1: 1.25$ & 20 & $3 \mathrm{~h}$ & $6 h$ & $\begin{array}{c}\mathrm{O}-t- \\
\mathrm{Bu}\end{array}$ & $\mathrm{H}$ & 40 & oil \\
\hline $4 \mathbf{j}$ & $\mathrm{Ph}$ & $\mathrm{Me}$ & I & $1: 1.7$ & 20 & $24 \mathrm{~h}$ & $\mathbf{6 j}$ & $\mathrm{H}$ & $\mathrm{H}$ & $-{ }_{-f}^{f}$ & - \\
\hline
\end{tabular}

${ }^{\mathrm{a}}$ Isolated yield. ${ }^{\mathrm{b}}$ Lit. $\mathrm{mp} 99-101^{\circ} \mathrm{C}$ (from hexane).$^{39 \mathrm{c}}$ The dimer $\mathbf{7}$ was also isolated in a yield of $33 \%$. ${ }^{\mathrm{d}}$ Lit. $\mathrm{mp} 41^{\circ} \mathrm{C} .{ }^{40 \mathrm{e}}$ Lit. $\mathrm{mp} 38.5-39^{\circ} \mathrm{C} .{ }^{41 \mathrm{f}}$ Enamide $\mathbf{6 j}$ was formed in the reaction mixture in a yield of $94 \%\left({ }^{1} \mathrm{H} \mathrm{NMR}\right)$. Attempts to isolate the enamide by column chromatography failed.

In most cases we were able to isolate enamides 6 in a pure form by the evaporation of the solvent and separation of the residue by column chromatography (Table 2), however, isolated yields of enamides were usually much lower than their contents in reaction mixtures. Attempts to isolate enamide $\mathbf{6 j}$ failed, in spite of its formation in the reaction mixture in a yield of $94 \%$. In the case of phosphonium salt $\mathbf{4 f}$, a compound $\mathbf{7}$ formed by the condensation of two molecules of phosphonium salt was isolated in a yield of 33\%, in addition to the expected $N$-acylenamide $\mathbf{6 f}$, isolated in a yield of $17 \%$ (Scheme 4).

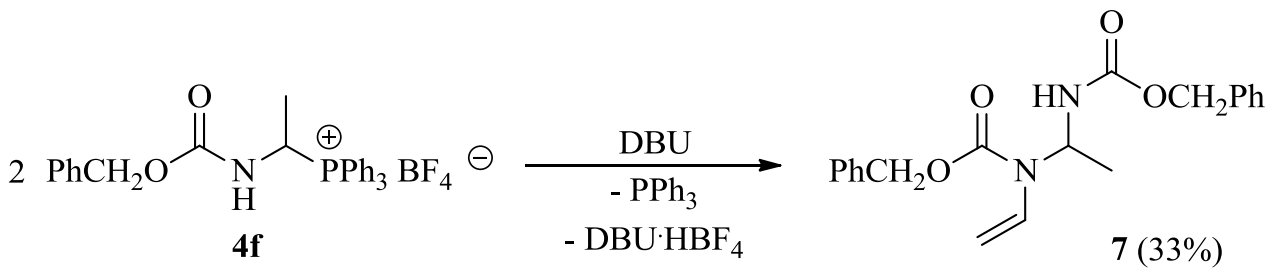

\section{Scheme 4}

Investigations on this reaction are in progress; nevertheless it is evident that compound 7 results from a novel aza-Morita-Baylis-Hillman-like reaction between the corresponding $N$ acylimine (as the electrophilic component) and $N$-deprotonated amidinium salt $\mathbf{5 h}$ (as the nucleophilic component). ${ }^{42}$ It seems, that dimer $\mathbf{7}$ is formed mainly during the work-up of the reaction mixture, as the isolated yield of this compound is much higher than its contents in the reaction mixture before the work-up. The increase of the concentration of reagents during evaporation of the solvent should facilitate the formation of the dimer in a second order reaction. 
The findings described above can be rationalised assuming that 1-(Nacylamino)alkyltriphenylphosphonium salts $\mathbf{4}$, when treated with base, undergo $\beta$-elimination to primarily produce the corresponding $N$-acylimines $\mathbf{2}$ by the expulsion of triphenylphosphine and the corresponding acid. The resulting $N$-acylimines, are strong amidoalkylation reagents and they in turn react with DBU, DBN or TBD to give amidinium or guanidinium salts $\mathbf{5}$. Salts $\mathbf{5}$ with a proton at the $\beta$-position undergo slow transformation directly, or more probably via $N$ acylimines, to the corresponding, more thermodynamically stable, enamides 6 . Tautomerisation of $\mathrm{N}$-acylimines into the corresponding enamides is a well-known phenomenon. ${ }^{7,43}$ In a few cases (compounds $\mathbf{5 c}, \mathbf{5 d}, \mathbf{5 h}$ and $\mathbf{5 k}$ ), the amidinium salts transformation to the corresponding enamides or $\mathrm{N}$-acylimines is probably so rapid that attempts to separate the polar salts from less polar compounds by extraction with toluene failed.

These conclusions were confirmed by the observation that not only phosphonium salts $\mathbf{4}$, but also amidinium or guanidinium salts 5 and enamides $\mathbf{6}$ all react easily with $\beta$-dicarbonyl compounds in the presence of the corresponding base under microwave irradiation at $60^{\circ} \mathrm{C}$ to give the expected product of $\alpha$-amidoalkylation of the corresponding enolate anion (Scheme 5, Table 3). It is well known that enamides can act as $\alpha$-amidoalkylating reagents, although usually alkylation occurs in acidic conditions with participation of the acyliminium cation resulting from the $\beta$-C-protonation of the enamide. ${ }^{44}$ The results of these experiments can be explained assuming that phosphonium salts $\mathbf{4}$, amidinium or guanidinium salts $\mathbf{5}$, enamides $\mathbf{6}$ and $\mathrm{N}$ acylimines 2 all remain in equilibrium under the applied reaction conditions.

At least two reasons can be responsible for the isolation of enamides $\mathbf{6}$ in much lower yields if compare with their contents in reaction mixtures: (i) enamides, remaining in equilibrium with highly reactive $\mathrm{N}$-acylimines $\mathbf{2}$, can be used up in side reactions with nucleophiles (eg. water from moisture) during their isolation and (ii) enamides, as components of the equilibrium mixture, can also be consumed in the aforementioned aza-Morita-Baylis-Hillman-like reaction.

Easily accessible 1-( $N$-acylamino)alkylamidinium or guanidinium salts 5 can be considered as new convenient $\alpha$-amidoalkylating reagents that do not introduce any by-products into the post-reaction mixture except for the required base. It is noteworthy that, in the case of these new $\alpha$-amidoalkylation agents, the base used plays a double role, acting as both the basic catalyst and the nucleofugal leaving group. 
Table 3. Phosphonium salts $\mathbf{4}$ and their derivatives as $\alpha$-amidoalkylating agents

\begin{tabular}{|c|c|c|c|c|c|c|c|c|c|c|c|c|c|}
\hline \multicolumn{5}{|c|}{$\begin{array}{c}\text { Amidoalkylating agent } \\
\text { AA }\end{array}$} & \multicolumn{3}{|c|}{$\mathrm{NuH}$} & \multirow{2}{*}{ Base } & \multirow{2}{*}{$\begin{array}{c}\text { Molar } \\
\text { ratio of } \\
\text { AA:NuH: } \\
\text { base }\end{array}$} & \multirow{2}{*}{ Time } & \multicolumn{3}{|c|}{ Product 8} \\
\hline & $\mathrm{R}^{1}$ & $\mathrm{R}^{2}$ & $\mathrm{R}^{3}$ & $X$ & $\mathrm{R}^{5}$ & $\mathrm{R}^{6}$ & $\mathrm{R}^{7}$ & & & & & Yield (\%) & $\operatorname{Mp}\left({ }^{\circ} \mathrm{C}\right)$ \\
\hline $4 \mathbf{a}$ & $\mathrm{Ph}$ & $\mathrm{H}$ & - & $\mathrm{BF}_{4}$ & $\mathrm{H}$ & $\mathrm{OMe}$ & $\mathrm{OMe}$ & $\mathrm{DBU}$ & $1: 8: 2$ & $1.5 \mathrm{~h}$ & $\mathbf{8 a}$ & 64 & $\begin{array}{l}94.0- \\
95.0\end{array}$ \\
\hline $5 \mathbf{a}$ & $\mathrm{Ph}$ & $\mathrm{H}$ & - & $\mathrm{BF}_{4}$ & $\mathrm{H}$ & $\mathrm{OMe}$ & $\mathrm{OMe}$ & DBU & $1: 8: 2$ & $1.5 \mathrm{~h}$ & $\mathbf{8 a}$ & 60 & $\begin{array}{l}94.5- \\
95.0\end{array}$ \\
\hline $4 c$ & $\mathrm{Me}$ & $\mathrm{Ph}$ & - & $\mathrm{BF}_{4}$ & $\mathrm{H}$ & $\mathrm{OMe}$ & $\mathrm{OMe}$ & $\mathrm{DBU}$ & $1: 8: 2$ & $2.0 \mathrm{~h}$ & $8 b$ & 96 & $\begin{array}{l}127.5- \\
129.0^{a}\end{array}$ \\
\hline $4 d$ & $t-\mathrm{Bu}$ & $\mathrm{Me}$ & - & I & $\mathrm{H}$ & OEt & OEt & DBU & $1: 6: 2$ & $1.5 \mathrm{~h}$ & $8 c$ & 61 & oil \\
\hline $6 d$ & $t-\mathrm{Bu}$ & - & $\mathrm{H}$ & - & $\mathrm{H}$ & $\mathrm{OEt}$ & OEt & $\mathrm{DBU}$ & $1: 6: 2$ & $1.0 \mathrm{~h}$ & $8 c$ & 82 & oil \\
\hline $4 e$ & $t-\mathrm{Bu}$ & $\mathrm{Me}$ & - & $\mathrm{BF}_{4}$ & $\mathrm{H}$ & $\mathrm{OMe}$ & $\mathrm{OMe}$ & DBU & $1: 8: 2$ & $2.0 \mathrm{~h}$ & $8 d$ & 79 & \\
\hline $5 f^{b}$ & $t-\mathrm{Bu}$ & $\mathrm{Me}$ & - & $\mathrm{BF}_{4}$ & $\mathrm{H}$ & $\mathrm{OMe}$ & $\mathrm{OMe}$ & DBN & $1: 8: 2$ & $2.0 \mathrm{~h}$ & $8 d$ & 80 & $\begin{array}{l}57.0- \\
58.0\end{array}$ \\
\hline $5 g^{b}$ & $t-\mathrm{Bu}$ & $\mathrm{Me}$ & - & $\mathrm{BF}_{4}$ & $\mathrm{H}$ & OMe & $\mathrm{OMe}$ & TBD & $1: 8: 2$ & $2.0 \mathrm{~h}$ & 8d & 88 & \\
\hline $4 f$ & $\mathrm{BnO}$ & $\mathrm{Me}$ & - & $\mathrm{BF}_{4}$ & $\mathrm{H}$ & $\mathrm{OMe}$ & $\mathrm{OMe}$ & $\mathrm{DBU}$ & $1: 8: 2$ & $3.5 \mathrm{~h}$ & $8 e$ & 70 & oil \\
\hline $4 k$ & $\mathrm{BnO}$ & $\mathrm{Ph}$ & - & $\mathrm{BF}_{4}$ & $\mathrm{H}$ & $\mathrm{OMe}$ & $\mathrm{OMe}$ & DBU & $1: 8: 2$ & $2.0 \mathrm{~h}$ & $8 f$ & 80 & $\begin{array}{l}\text { waxy } \\
\text { solid }\end{array}$ \\
\hline 41 & $\mathrm{Me}$ & $\mathrm{H}$ & - & $\mathrm{BF}_{4}$ & $\mathrm{Me}$ & $\mathrm{Me}$ & $\mathrm{OEt}$ & $\mathrm{DBU}$ & $1: 2: 1.5$ & $2.0 \mathrm{~h}$ & $8 g$ & 85 & oil \\
\hline 41 & $\mathrm{Me}$ & $\mathrm{H}$ & - & $\mathrm{BF}_{4}$ & $\mathrm{H}$ & $\mathrm{Me}$ & OEt & DBU & $1: 6: 2$ & $2.5 \mathrm{~h}$ & $8 h$ & 70 & oil \\
\hline
\end{tabular}

${ }^{\text {a Lit. } \mathrm{mp}} 126-127^{\circ} \mathrm{C} .{ }^{45}$

${ }^{\mathrm{b}}$ Prepared in situ. 
<smiles>[R]C(=O)NC([R])[Pb]</smiles>

4<smiles>[R]C(=O)NC([R2])[N+]1=C2CCCN(CC2)CC1</smiles>
5<smiles>[R]C=CNC([R])=O</smiles>

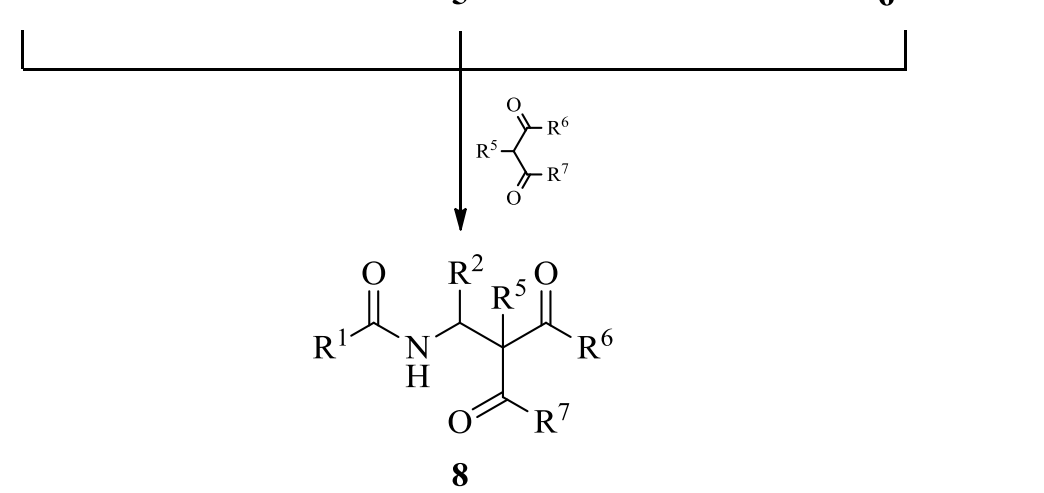

\section{Scheme 5}

\section{Conclusions}

In conclusion, 1-( $N$-acylamino)alkyltriphenylphosphonium salts 4, when treated with DBU, DBN or TBD, undergo immediate $\beta$-elimination to the corresponding $N$-acylimines $\mathbf{2}$ by the loss of triphenylphosphine and the corresponding acid. $N$-Acylimines, as strong amidoalkylation reagents, quickly react in turn with the corresponding base to give amidinium or guanidinium salts 5. Salts 5 with a proton at the $\beta$-position undergo slow transformation directly, or more probably, via $\mathrm{N}$-acylimines to the corresponding enamides $\mathbf{6}$, as more thermodynamically stable compounds. Phosphonium salts 4, amidinium or guanidinium salts $\mathbf{5}$, enamides $\mathbf{6}$ and $N$ acylimines 2 remain in equilibrium under the applied reaction conditions. As a result, not only salts 4 , but also amidinium or guanidinium salts 5 and enamides 6 all react easily in the presence of the corresponding base under the influence of microwave irradiation at $60^{\circ} \mathrm{C}$ with $\beta$ dicarbonyl compounds to give the expected product of $\alpha$-amidoalkylation. Easily accessible 1( $N$-acylamino)alkylamidinium or guanidinium salts $\mathbf{5}$ are novel, interesting amidoalkylating reagents that do not result in the production of any by-products (except for the base) in the postreaction mixture.

\section{Experimental Section}

General. Commercial grade $\mathrm{CH}_{2} \mathrm{Cl}_{2}, \mathrm{MeCN}$, AcOEt, toluene and hexane were distilled and dried over molecular sieves ( $4 \AA$ ). The following reagents were purchased from the Sigma-Aldrich 
company and were used as supplied: DBU, DBN, TBD, dimethyl malonate, ethyl acetoacetate, ethyl 2-methylacetoacetate and diethyl malonate. Melting points were determined in capillary tubes in a Stuart Scientific SMP3 melting point apparatus, and were uncorrected. IR spectra were recorded on a Nicolet 6700 FT-IR or Zeiss Specord 80. NMR spectra were recorded in $\mathrm{CD}_{3} \mathrm{CN}$ or $\mathrm{CDCl}_{3}$ in FT mode using TMS as an internal standard. ${ }^{1} \mathrm{H}$ and ${ }^{13} \mathrm{C}$ NMR spectra were recorded on a Varian UNITY INOVA-300 spectrometer at 300 and $75 \mathrm{MHz}$, respectively. Mass spectra were recorded on a AMD604 Intectra $\mathrm{GmbH}$ spectrometer using Electron Ionisation, on a Mariner spectrometer using Electrospray Ionisation or on a GCT Premier (Waters) specrometer using Field Desorption Ionisation. Reactions requiring microwave irradiation were carried out using a CEM Matthews microwave reactor. Kieselgel 60 (Merck, 0.063-0.200 mm) was used for column chromatography.

\section{Procedure for the synthesis of amidinium or guanidinium salts (5)}

DBU, DBN or TBD in amounts given in Table 1, was added to a suspension of phosphonium salt $4(1 \mathrm{mmol})$ in $\mathrm{MeCN}(11 \mathrm{~mL})$ at $20^{\circ} \mathrm{C}$. After $10 \mathrm{~min}$, the solvent was evaporated under reduced pressure, and the residue was washed with toluene at room temperature and dried under reduced pressure to give amidinium or guanidinium salts 5 in varying yields (Table 1). Spectral properties and analytical data of amidinium salts $\mathbf{5 a}, \mathbf{5 b}, \mathbf{5 e}$ and $\mathbf{5 m}$ were already reported in our previous paper. $^{15}$

8-[1-(N-Acetylamino)phenylmethyl]-1-aza-8-azoniabicyclo[5.4.0.]undec-7-ene tetrafluoroborate $(5 \mathrm{c}) .{ }^{1} \mathrm{H} \mathrm{NMR}\left(300 \mathrm{MHz}, \mathrm{CD}_{3} \mathrm{CN}\right): \delta_{\mathrm{H}} 1.56-1.90(8 \mathrm{H}, \mathrm{m}, 4 \mathrm{xCH}), 2.06\left(3 \mathrm{H}, \mathrm{s}, \mathrm{CH}_{3} \mathrm{CO}\right)$, 2.90-3.00 (2H, m, $\left.\mathrm{CH}_{2}\right), 3.12-3.22\left(2 \mathrm{H}, \mathrm{m}, \mathrm{CH}_{2}\right), 3.28-3.42\left(2 \mathrm{H}, \mathrm{m}, \mathrm{CH}_{2}\right), 3.44-3.64(2 \mathrm{H}, \mathrm{m}$, $\left.\mathrm{CH}_{2}\right), 7.01\left(1 \mathrm{H}\right.$, br s, CH), 7.24-7.42 (5H, m, Ph), $7.84\left(1 \mathrm{H}, \mathrm{d}, J_{H H}=6.6 \mathrm{~Hz}, \mathrm{NH}\right)$.

5-[1-(N-Acetylamino)phenylmethyl]-1-aza-5-azoniabicyclo[4.3.0.]non-5-ene tetrafluoroborate (5d). ${ }^{1} \mathrm{H}$ NMR $\left(300 \mathrm{MHz}, \mathrm{CD}_{3} \mathrm{CN}\right): \delta_{\mathrm{H}} 1.78-1.90\left(4 \mathrm{H}, \mathrm{m}, 2 \mathrm{xCH}_{2}\right), 2.03\left(3 \mathrm{H}, \mathrm{s}, \mathrm{CH}_{3} \mathrm{CO}\right)$, 3.09-3.26 (8H, m, 4xCH $), 6.94(1 \mathrm{H}$, br s, $\mathrm{CH}), 7.24-7.40(6 \mathrm{H}, \mathrm{m}, \mathrm{Ph}+\mathrm{NH})$.

\section{5-[1-( $N$-Pivaloylamino)ethyl]-1-aza-5-azoniabicyclo[4.3.0.]non-5-ene tetrafluoroborate $(5 f)$.} Colourless oil, $316 \mathrm{mg}$, yield 93\%. IR $\left(v_{\max }, \mathrm{cm}^{-1}\right): 3394(\mathrm{~N}-\mathrm{H}), 1660(\mathrm{C}=\mathrm{O}+\mathrm{C}=\mathrm{N}), 1047(\mathrm{C}-$ $\left.\mathrm{N}^{+}\right) .{ }^{1} \mathrm{H}$ NMR $\left(300 \mathrm{MHz}, \mathrm{CD}_{3} \mathrm{CN}\right): \delta_{\mathrm{H}} 1.15(9 \mathrm{H}, \mathrm{s}, t-\mathrm{Bu}), 1.44\left(3 \mathrm{H}, \mathrm{d}, J_{H H}=6.9 \mathrm{~Hz}, \mathrm{CH}_{3}\right), 1.76-$ $2.06\left(2 \mathrm{H}, \mathrm{m}, \mathrm{CH}_{2}\right), 2.06-2.20\left(2 \mathrm{H}, \mathrm{m}, \mathrm{CH}_{2}\right), 3.22-3.38\left(6 \mathrm{H}, \mathrm{m}, 3 \mathrm{xCH}_{2}\right), 3.54-3.70\left(2 \mathrm{H}, \mathrm{m}, \mathrm{CH}_{2}\right)$, $5.46\left(1 \mathrm{H}, \mathrm{dq}, J_{H H}^{1}=6.9 \mathrm{~Hz}, J_{H H}^{2}=6.6 \mathrm{~Hz}, \mathrm{CH}\right), 7.02\left(1 \mathrm{H}\right.$, br s, NH). ${ }^{13} \mathrm{C} \mathrm{NMR}(75 \mathrm{MHz}$,

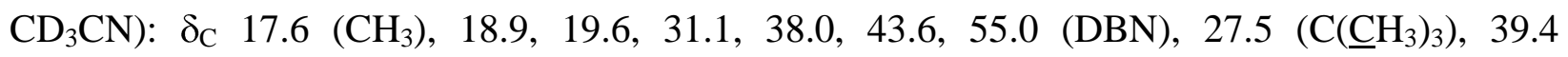
$\left(\underline{\mathrm{C}}\left(\mathrm{CH}_{3}\right)_{3}\right), 64.1(\mathrm{CH}), 165.2(\mathrm{C}=\mathrm{N}), 179.9(\mathrm{C}=\mathrm{O})$.

5-[1-(N-Pivaloylamino)ethyl]-1,7-diaza-5-azoniabicyclo[4.4.0.]dec-5-ene tetrafluoroborate (5g). Colourless oil, $344 \mathrm{mg}$, yield 97\%. IR $\left(v_{\max }, \mathrm{cm}^{-1}\right): 3394(\mathrm{~N}-\mathrm{H}), 1625(\mathrm{C}=\mathrm{O}+\mathrm{C}=\mathrm{N}), 1050$

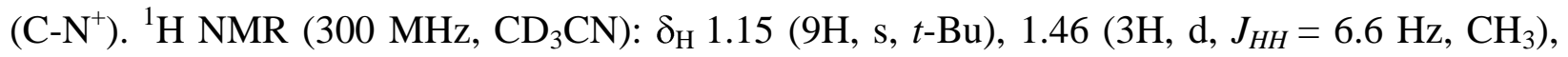
1.86-2.00 (4H, m, 2xCH $), 3.16-3.36\left(8 \mathrm{H}, \mathrm{m}, 4 \mathrm{xCH}_{2}\right), 5.52\left(1 \mathrm{H}, \mathrm{q}, J_{H H}=6.6 \mathrm{~Hz}, \mathrm{CH}\right), 7.71(1 \mathrm{H}$, $\left.\mathrm{d}, J_{H H}=7.5 \mathrm{~Hz}, \mathrm{NH}\right) .{ }^{13} \mathrm{C} \mathrm{NMR}\left(75 \mathrm{MHz}, \mathrm{CD}_{3} \mathrm{CN}\right): \delta_{\mathrm{C}} 18.1\left(\mathrm{CH}_{3}\right), 21.4,22.1,38.9,39.1,39.5$, 48.2, $48.5\left(\mathrm{TBD}\right.$ and $\left.\underline{\mathrm{C}}\left(\mathrm{CH}_{3}\right)_{3}\right), 27.4\left(\mathrm{C}\left(\underline{\mathrm{CH}}_{3}\right)_{3}\right), 60.3(\mathrm{CH}), 152.1(\mathrm{C}=\mathrm{N}), 181.5(\mathrm{C}=\mathrm{O})$. 
8-[1-( $N$-Benzyloxycarbonylamino)ethyl]-1-aza-8-azoniabicyclo[5.4.0.]undec-7-ene tetrafluoroborate (5h). ${ }^{1} \mathrm{H} \mathrm{NMR}\left(300 \mathrm{MHz}, \mathrm{CD}_{3} \mathrm{CN}\right): \delta_{\mathrm{H}} 1.40\left(3 \mathrm{H}, \mathrm{d}, J_{\mathrm{HH}}=6.6 \mathrm{~Hz}, \mathrm{CH}_{3}\right), 1.58$ $1.73\left(6 \mathrm{H}, \mathrm{m}, 3 \mathrm{xCH}_{2}\right), 1.84-1.92\left(2 \mathrm{H}, \mathrm{m}, \mathrm{CH}_{2}\right), 3.16-3.26\left(2 \mathrm{H}, \mathrm{m}, \mathrm{CH}_{2}\right), 3.33-3.45(6 \mathrm{H}, \mathrm{m}$, $\left.3 \mathrm{xCH}_{2}\right), 5.08\left(2 \mathrm{H}, \mathrm{s}, \mathrm{PhCH}_{2}\right), 5.75\left(1 \mathrm{H}, \mathrm{dq}, J_{H H}^{l}=J_{H H}^{2}=7.0 \mathrm{~Hz}, \mathrm{CH}\right), 7.34-7.43(6 \mathrm{H}, \mathrm{m}$, $\mathrm{Ph}+\mathrm{NH})$.

5-[1-(N-Benzyloxycarbonylamino)ethyl]-1-aza-5-azoniabicyclo[4.3.0.]non-5-ene tetrafluoroborate (5i). Colourless oil, $339 \mathrm{mg}$, yield 87\%. IR $\left(v_{\max }, \mathrm{cm}^{-1}\right): 3361(\mathrm{~N}-\mathrm{H}), 1721$ $(\mathrm{C}=\mathrm{O}), 1655(\mathrm{C}=\mathrm{N}), 1036\left(\mathrm{C}-\mathrm{N}^{+}\right) .{ }^{1} \mathrm{H}$ NMR $\left(300 \mathrm{MHz}, \mathrm{CD}_{3} \mathrm{CN}\right): \delta_{\mathrm{H}} 1.40\left(3 \mathrm{H}, \mathrm{d}, J_{H H}=6.3 \mathrm{~Hz}\right.$, $\left.\mathrm{CH}_{3}\right), 1.80-2.04\left(2 \mathrm{H}, \mathrm{m}, \mathrm{CH}_{2}\right), 2.04-2.20\left(2 \mathrm{H}, \mathrm{m}, \mathrm{CH}_{2}\right), 3.16-3.42\left(6 \mathrm{H}, \mathrm{m}, 3 \mathrm{xCH}_{2}\right), 3.58-3.74$ $\left(2 \mathrm{H}, \mathrm{m}, \mathrm{CH}_{2}\right), 5.05\left(1 \mathrm{H}, \mathrm{d}, J_{H H}=14.1 \mathrm{~Hz}, \mathrm{PhCH}_{2}{ }^{\mathrm{a}}\right), 5.11\left(1 \mathrm{H}, \mathrm{d}, J_{H H}=14.1 \mathrm{~Hz}, \mathrm{PhCH}_{2}{ }^{\mathrm{a}}\right), 5.32-$ $5.44(1 \mathrm{H}, \mathrm{m}, \mathrm{CH}), 6.63(1 \mathrm{H}, \mathrm{br} \mathrm{s}, \mathrm{NH}), 7.30-7.48(5 \mathrm{H}, \mathrm{m}, \mathrm{Ph}) .{ }^{13} \mathrm{C} \mathrm{NMR}\left(75 \mathrm{MHz}, \mathrm{CD}_{3} \mathrm{CN}\right): \delta_{\mathrm{C}}$ $17.9\left(\mathrm{CH}_{3}\right), 18.9,19.6,31.2,37.9,43.6,55.1(\mathrm{DBN}), 65.8(\mathrm{CH}), 67.6\left(\mathrm{PhCH}_{2}\right), 128.7,129.3$, 129.6, 137.7 (aromatic carbons), $156.4(\mathrm{C}=\mathrm{O}), 165.1(\mathrm{C}=\mathrm{N})$.

5-[1-( $N$-Benzyloxycarbonylamino)ethyl]-1,7-diaza-5-azoniabicyclo[4.4.0.]dec-5-ene tetrafluoroborate $(\mathbf{5 j})$. Orange oil, $392 \mathrm{mg}$, yield 97\%. IR $\left(v_{\max }, \mathrm{cm}^{-1}\right): 3369(\mathrm{~N}-\mathrm{H}), 1698$ $(\mathrm{C}=\mathrm{O}), 1598(\mathrm{C}=\mathrm{N}), 1051\left(\mathrm{C}_{-} \mathrm{N}^{+}\right) .{ }^{1} \mathrm{H}$ NMR $\left(300 \mathrm{MHz}, \mathrm{CD}_{3} \mathrm{CN}\right): \delta_{\mathrm{H}} 1.41\left(3 \mathrm{H}, \mathrm{d}, J_{H H}=6.3 \mathrm{~Hz}\right.$, $\left.\mathrm{CH}_{3}\right), 1.82-2.02\left(4 \mathrm{H}, \mathrm{m}, 2 \mathrm{xCH}_{2}\right), 3.12-3.40\left(8 \mathrm{H}, \mathrm{m}, 4 \mathrm{xCH}_{2}\right), 5.08\left(1 \mathrm{H}, \mathrm{d}, J_{H H}=10.2 \mathrm{~Hz}\right.$, $\left.\mathrm{PhCH}_{2}{ }^{\mathrm{a}}\right), 5.13\left(1 \mathrm{H}, \mathrm{d}, J_{H H}=12.6 \mathrm{~Hz}, \mathrm{PhCH}_{2}{ }^{\mathrm{a}}\right), 5.41\left(1 \mathrm{H}, \mathrm{dq}, J_{H H}^{l}=7.2 \mathrm{~Hz}, J^{2}{ }_{H H}=6.0 \mathrm{~Hz}, \mathrm{CH}\right)$, $6.71\left(1 \mathrm{H}\right.$, br s, NH), 7.30-7.44 (5H, m, Ph), $7.50\left(1 \mathrm{H}\right.$, br s, NH). ${ }^{13} \mathrm{C}$ NMR $\left(75 \mathrm{MHz}, \mathrm{CD}_{3} \mathrm{CN}\right)$ : $\delta_{\mathrm{C}} 18.5\left(\mathrm{CH}_{3}\right), 21.4,22.0,39.0,39.5,48.2,48.5(\mathrm{TBD}), 61.2(\mathrm{CH}), 68.0\left(\mathrm{PhCH}_{2}\right), 128.9,129.2$, 129.6, 137.4 (aromatic carbons), $152.8(\mathrm{C}=\mathrm{N}), 158.0(\mathrm{C}=\mathrm{O})$.

${ }^{a}$ Diastereotopic protons

8-[1-( $N$-Benzyloxycarbonylamino)-2-methylpropyl]-1-aza-8-azoniabicyclo[5.4.0.]undec-7ene tetrafluoroborate (5k). ${ }^{1} \mathrm{H} \mathrm{NMR}\left(300 \mathrm{MHz}, \mathrm{CD}_{3} \mathrm{CN}\right): \delta_{\mathrm{H}} 0.88\left(3 \mathrm{H}, \mathrm{d}, J_{H H}=5.4 \mathrm{~Hz}, \mathrm{CH}_{3}{ }^{\mathrm{a}}\right)$, $0.90\left(3 \mathrm{H}, \mathrm{d}, J_{H H}=4.5 \mathrm{~Hz}, \mathrm{CH}_{3}{ }^{\mathrm{a}}\right), 1.58-1.78\left(6 \mathrm{H}, \mathrm{m}, 3 \mathrm{XCH}_{2}\right), 1.82-1.92\left(2 \mathrm{H}, \mathrm{m}, \mathrm{CH}_{2}\right), 2.46-2.56$ $\left(1 \mathrm{H}, \mathrm{m}, \mathrm{CH}\left(\mathrm{CH}_{3}\right)_{2}\right), 3.16-3.24\left(4 \mathrm{H}, \mathrm{m}, 2 \mathrm{xCH}_{2}\right), 3.32-3.46\left(4 \mathrm{H}, \mathrm{m}, 2 \mathrm{xCH}_{2}\right), 5.08(2 \mathrm{H}, \mathrm{br} \mathrm{s}$, $\left.\mathrm{PhCH}_{2}\right)$, 5.18-5.30 (1H, m, CH), 7.22-7.44 (6H, m, Ph+NH).

${ }^{\text {a }}$ Diastereotopic protons

8-[1-(N-Benzyloxycarbonylamino)-2-t-buthoxyethyl]-1-aza-8-azoniabicyclo[5.4.0.]undec-7ene tetrafluoroborate (5l). Colourless oil, $392 \mathrm{mg}$, yield 80\%. IR $\left(v_{\max }, \mathrm{cm}^{-1}\right): 3355(\mathrm{~N}-\mathrm{H})$, $1723(\mathrm{C}=\mathrm{O}), 1609(\mathrm{C}=\mathrm{N}), 1024\left(\mathrm{C}_{-} \mathrm{N}^{+}\right) .{ }^{1} \mathrm{H}$ NMR $\left(300 \mathrm{MHz}, \mathrm{CD}_{3} \mathrm{CN}\right): \delta_{\mathrm{H}} 1.17(9 \mathrm{H}, \mathrm{s}, t-\mathrm{Bu})$, 1.60-1.80 (6H, m, 3xCH 2$), 1.80-2.00\left(2 \mathrm{H}, \mathrm{m}, \mathrm{CH}_{2}\right), 2.84-3.14\left(2 \mathrm{H}, \mathrm{m}, \mathrm{CH}_{2}\right), 3.24-3.32(2 \mathrm{H}, \mathrm{m}$, $\left.\mathrm{CH}_{2}\right), 3.36-3.48\left(2 \mathrm{H}, \mathrm{m}, \mathrm{CH}_{2}\right), 3.48-3.56\left(2 \mathrm{H}, \mathrm{m}, \mathrm{CH}_{2}\right), 3.56-3.70\left(2 \mathrm{H}, \mathrm{m}, \mathrm{CH}_{2}\right), 5.10(2 \mathrm{H}$, br s, $\left.\mathrm{PhCH}_{2}\right)$, 5.64-5.76 (1H, m, CH), $6.66\left(1 \mathrm{H}\right.$, br s, NH), 7.30-7.42 (5H, m, Ph). ${ }^{13} \mathrm{C}$ NMR $(75 \mathrm{MHz}$, $\left.\mathrm{CD}_{3} \mathrm{CN}\right): \delta_{\mathrm{C}} 20.6,22.9,26.6,28.5,28.8,40.0,50.3,55.4(\mathrm{DBU}), 27.6\left(\mathrm{C}\left(\mathrm{CH}_{3}\right)_{3}\right), 60.5\left(\mathrm{CH}_{2}\right)$, $67.8(\mathrm{CH}), 68.2\left(\mathrm{PhCH}_{2}\right), 74.9\left(\underline{\mathrm{C}}\left(\mathrm{CH}_{3}\right)_{3}\right), 129.3,129.6,130.0,139.0$ (aromatic carbons), 156.5 $(\mathrm{C}=\mathrm{O}), 168.4(\mathrm{C}=\mathrm{N})$. 


\section{Procedures for the synthesis of enamides (6)}

DBU, in amounts given in Table 2, was added to a suspension of phosphonium salt 4 (1 mmol) in $\mathrm{MeCN}(11 \mathrm{~mL})$. The reaction mixture was left for the time indicated in Table 2 at room temperature and then the solvent was evaporated under reduced pressure. The resulting enamide 6 was then isolated by column chromatography (silica gel, EtOAc/toluene 1:2) in a yield given in Table 2. Spectral properties and analytical data of compound $\mathbf{6 d}$ were already reported in our previous paper. ${ }^{15}$ In the case of synthesis of enamide $\mathbf{6} \mathbf{f}$ compound 7 was also isolated.

Benzyl $N$-vinylcarbamate (6f). Colourless solid, $30.1 \mathrm{mg}$, yield 17\%. IR $\left(v_{\max }, \mathrm{cm}^{-1}\right)$ : $3272(\mathrm{~N}-$ $\mathrm{H}), 1694(\mathrm{C}=\mathrm{O}), 1645(\mathrm{C}=\mathrm{C}), 1530(\mathrm{~N}-\mathrm{H}), 1252$ (C-N), 1081 (C-O). ${ }^{1} \mathrm{H}$ NMR (300 MHz, $\left.\mathrm{CD}_{3} \mathrm{CN}\right): \delta_{\mathrm{H}} 4.23\left(1 \mathrm{H}, \mathrm{d}, J_{H H}=8.7 \mathrm{~Hz}, \mathrm{CH}=\underline{\mathrm{CH}}_{2}\right), 4.56\left(1 \mathrm{H}, \mathrm{d}, J_{H H}=15.9 \mathrm{~Hz}, \mathrm{CH}=\underline{\mathrm{C}}_{2}\right), 5.1$ $\left(2 \mathrm{H}, \mathrm{s}, \mathrm{PhCH}_{2}\right), 6.64\left(1 \mathrm{H}, \mathrm{ddd}, J^{1}{ }_{H H}=15.9 \mathrm{~Hz}, J^{2}{ }_{H H}=10.7 \mathrm{~Hz}, J^{3}{ }_{H H}=6.9 \mathrm{~Hz}, \mathrm{C} \underline{\mathrm{H}}=\mathrm{CH}_{2}\right), 7.28-$ $7.45(5 \mathrm{H}, \mathrm{m}, \mathrm{Ph}), 7.65\left(1 \mathrm{H}\right.$, br s, NH). ${ }^{13} \mathrm{C} \mathrm{NMR}\left(75 \mathrm{MHz}, \mathrm{CD}_{3} \mathrm{CN}\right): \delta_{\mathrm{C}} 67.4\left(\mathrm{PhCH}_{2}\right), 93.6$ $\left(\mathrm{CH}=\underline{\mathrm{CH}}_{2}\right), 128.8,129.1,129.5,137.8$ (aromatic carbons), $131.3\left(\underline{\mathrm{CH}}=\mathrm{CH}_{2}\right), 154.8(\mathrm{C}=\mathrm{O})$, identical by comparisons with literature data. ${ }^{40}$

Benzyl N-2,2-dimethylvinylcarbamate (6g). Colourless solid, $127 \mathrm{mg}$, yield $62 \%$. ${ }^{1} \mathrm{H}$ NMR $\left(300 \mathrm{MHz}, \mathrm{CD}_{3} \mathrm{CN}\right): \delta_{\mathrm{H}} 1.58\left(3 \mathrm{H}, \mathrm{s}, \mathrm{CH}_{3}\right), 1.65\left(3 \mathrm{H}, \mathrm{s}, \mathrm{CH}_{3}\right), 5.09\left(2 \mathrm{H}, \mathrm{s}, \mathrm{PhCH}_{2}\right), 6.17(1 \mathrm{H}, \mathrm{d}$, $\left.J_{H H}=9.9 \mathrm{~Hz}, \mathrm{CH}\right), 7.05(1 \mathrm{H}$, br s, NH), 7.32-7.38 $(5 \mathrm{H}, \mathrm{m}, \mathrm{Ph})$, identical by comparisons with literature data. ${ }^{41}$

(E)-Benzyl $\boldsymbol{N}$-(2-t-buthoxyvinyl)carbamate (6h). Colourless oil, $99.7 \mathrm{mg}$, yield 40\%. IR ( $v_{\max }$, $\left.\mathrm{cm}^{-1}\right)$ : $3449(\mathrm{~N}-\mathrm{H}), 1719(\mathrm{C}=\mathrm{O}), 1489(\mathrm{C}=\mathrm{C}), 1212(\mathrm{C}-\mathrm{N}), 1084(\mathrm{C}-\mathrm{O}) .{ }^{1} \mathrm{H}$ NMR (300 MHz, $\left.\mathrm{CD}_{3} \mathrm{CN}\right): \delta_{\mathrm{H}} 1.26(9 \mathrm{H}, \mathrm{s}, t-\mathrm{Bu}), 5.10\left(2 \mathrm{H}, \mathrm{s}, \mathrm{PhCH}_{2}\right), 5.81\left(1 \mathrm{H}, \mathrm{dd}, J^{1}{ }_{H H}=12.3 \mathrm{~Hz}, J^{2}{ }_{H H}=4.8 \mathrm{~Hz}\right.$, C $\left.\mathrm{CD}_{3} \mathrm{CN}\right): \delta_{\mathrm{C}} 27.9\left(\mathrm{C}\left(\underline{\mathrm{CH}}_{3}\right)_{3}\right), 67.3\left(\mathrm{PhCH}_{2}\right), 77.3\left(\underline{\mathrm{C}}\left(\mathrm{CH}_{3}\right)_{3}\right), 106.9(\mathrm{CH}=\underline{\mathrm{CH}}-\mathrm{O}-t-\mathrm{Bu}), 125.9$ $(\underline{\mathrm{CH}}=\mathrm{CH}-\mathrm{O}-t-\mathrm{Bu}), 128.7,128.9,129.4,137.9$ (aromatic carbons), $154.4(\mathrm{C}=\mathrm{O}) . \mathrm{HR}$ MS (EI) Calcd for $\left[\mathrm{M}^{+}\right] \mathrm{C}_{14} \mathrm{H}_{19} \mathrm{NO}_{3} 249.1365$, Found: 249.1362.

$N$-vinylbenzamide (6j, prepared in situ). ${ }^{1} \mathrm{H}$ NMR $\left(300 \mathrm{MHz}, \mathrm{CDCl}_{3}\right): \delta_{\mathrm{H}} 4.54\left(1 \mathrm{H}, \mathrm{d}, J_{H H}=8.7\right.$ $\left.\mathrm{Hz}, \mathrm{CH}=\underline{\mathrm{C}}_{2}\right), 4.80\left(1 \mathrm{H}, \mathrm{d}, J_{H H}=15.9 \mathrm{~Hz}, \mathrm{CH}=\mathrm{CH}_{2}\right), 7.20\left(1 \mathrm{H}, \mathrm{dd}, J^{1}{ }_{H H}=8.7 \mathrm{~Hz}, J^{2}{ }_{H H}=15.9\right.$ $\left.\mathrm{Hz}, \quad \mathrm{C} \underline{\mathrm{H}}=\mathrm{CH}_{2}\right), 7.44-7.57(4 \mathrm{H}, \mathrm{m}, \mathrm{Ph}+\mathrm{NH}), 7.83\left(2 \mathrm{H}, \mathrm{d}, J_{H H}=6.6 \mathrm{~Hz}, \mathrm{Ph}\right)$, identical by comparisons with literature data. ${ }^{46}$

Benzyl $N$-[1-(benzyloxycarbonylamino)ethyl]- $N$-vinylcarbamate (7). Colourless oil, $58.5 \mathrm{mg}$, yield 33\%. IR $\left(v_{\max }, \mathrm{cm}^{-1}\right): 1698(\mathrm{C}=\mathrm{O}), 1629(\mathrm{C}=\mathrm{C}), 1302(\mathrm{C}-\mathrm{N}), 1231(\mathrm{C}-\mathrm{N}), 1058(\mathrm{C}-\mathrm{O}) .{ }^{1} \mathrm{H}$ NMR $\left(300 \mathrm{MHz}, \mathrm{CD}_{3} \mathrm{CN}\right): \delta_{\mathrm{H}} 1.47\left(3 \mathrm{H}, \mathrm{d}, J_{H H}=6.6 \mathrm{~Hz}, \mathrm{CH}_{3}\right), 4.41\left(1 \mathrm{H}, \mathrm{d}, J_{H H}=9.6 \mathrm{~Hz}\right.$, $\left.\mathrm{CH}=\underline{\mathrm{C}}_{2}\right), 4.80\left(1 \mathrm{H}, \mathrm{d}, J_{H H}=16.2 \mathrm{~Hz}, \mathrm{CH}=\underline{\mathrm{CH}}_{2}\right), 5.02\left(1 \mathrm{H}, \mathrm{d}, J_{H H}=12.6 \mathrm{~Hz}, \mathrm{PhCH}_{2}{ }^{\mathrm{a}}\right), 5.08$ $\left(1 \mathrm{H}, \mathrm{d}, J_{H H}=12.6 \mathrm{~Hz}, \mathrm{PhCH}_{2}{ }^{\mathrm{a}}\right), 5.17\left(2 \mathrm{H}, \mathrm{s}, \mathrm{PhCH}_{2}\right), 5.74\left(1 \mathrm{H}, \mathrm{dq}, J^{1}{ }_{H H}=8.7 \mathrm{~Hz}, J^{2}{ }_{H H}=6.8 \mathrm{~Hz}\right.$, $\left.\mathrm{CH}_{-}-\mathrm{CH}_{3}\right), 6.48\left(1 \mathrm{H}, \mathrm{d}, J_{H H}=7.2 \mathrm{~Hz}, \mathrm{NH}\right), 6.79\left(1 \mathrm{H}, \mathrm{dd}, J_{H H}^{l}=15.9 \mathrm{~Hz}, J_{H H}^{2}=9.6 \mathrm{~Hz}\right.$, $\left.\mathrm{C} \underline{H}=\mathrm{CH}_{2}\right), 7.25-7.45(10 \mathrm{H}, \mathrm{m}, 2 \mathrm{xPh}) .{ }^{13} \mathrm{C} \mathrm{NMR}\left(75 \mathrm{MHz}, \mathrm{CD}_{3} \mathrm{CN}\right): \delta_{\mathrm{C}} 19.2\left(\mathrm{CH}_{3}\right), 61.0(\underline{\mathrm{CH}}-$ $\left.\mathrm{CH}_{3}\right), 67.2\left(\mathrm{PhCH}_{2}\right), 68.2\left(\mathrm{PhCH}_{2}\right), 95.8\left(\mathrm{CH}=\underline{\mathrm{CH}}_{2}\right), 128.8,128.9,129.0,129.1,129.4,129.5$, 137.5, 138.0 (aromatic carbons), $132.8\left(\underline{\mathrm{CH}}=\mathrm{CH}_{2}\right), 154.1(\mathrm{C}=\mathrm{O}), 156.1(\mathrm{C}=\mathrm{O})$. HR MS (ESI) Calcd for $[\mathrm{M}+\mathrm{Na}]^{+} \mathrm{C}_{20} \mathrm{H}_{22} \mathrm{~N}_{2} \mathrm{O}_{4} \mathrm{Na} 377.1472$, Found: 377.1480 . 
Amidoalkylation of $\beta$-dicarbonyl compounds with 1-( $N$-acylamino)alkyltriphenylphosphonium salts (4) or their derivatives

\section{General procedure}

Reactions were carried out in a glass vial sealed with a screw cap. A solution of nucleophilic reagent and base (in amounts given in Table 3) in MeCN (4.0 mL) was added to a solution of 1( $N$-acylamino)alkyltriphenylphosphonium salt $\mathbf{4}$ or amidinium salt $\mathbf{5 a}$, or enamide $\mathbf{6 d}(1 \mathrm{mmol})$ in $\mathrm{MeCN}$ (4.0 mL). The mixture was irradiated at a power of $10-12 \mathrm{~W}$ at $60^{\circ} \mathrm{C}$ in a microwave reactor for the time given in Table 3. The solvent was then evaporated under reduced pressure, and the product was isolated by column chromatography (silica gel, toluene/EtOAc 10:1 to 1:2; only in the case of compound $\mathbf{8 f} \mathrm{CH}_{2} \mathrm{Cl}_{2}$ was used). Compounds $\mathbf{8 b}$ and $\mathbf{8 d}$ were recrystallised by dissolving in toluene and precipitation with hexane. Spectral properties and analytical data of compounds $8 \mathbf{a}$ and $\mathbf{8 c}$ were already reported in our previous paper. ${ }^{15}$

Dimethyl 2-(acethylaminophenylmethyl)malonate (8b). White solid, $268 \mathrm{mg}$, yield $96 \%{ }^{1} \mathrm{H}$ NMR $\left(300 \mathrm{MHz}, \mathrm{CDCl}_{3}\right): \delta_{\mathrm{H}} 2.05\left(3 \mathrm{H}, \mathrm{s}, \mathrm{CH}_{3}\right), 3.65\left(3 \mathrm{H}, \mathrm{s}, \mathrm{OCH}_{3}\right), 3.76\left(3 \mathrm{H}, \mathrm{s}, \mathrm{OCH}_{3}\right), 3.96$ $\left(1 \mathrm{H}, \mathrm{d}, J_{H H}=4.5 \mathrm{~Hz}, \mathrm{CH}\right), 5.82\left(1 \mathrm{H}, \mathrm{dd}, J^{l}{ }_{H H}=9.4 \mathrm{~Hz}, J^{2}{ }_{H H}=4.1 \mathrm{~Hz}, \mathrm{NH}-\mathrm{CH}\right), 7.20(1 \mathrm{H}, \mathrm{br}$, $\mathrm{NH}), 7.23-7.36(5 \mathrm{H}, \mathrm{m}, \mathrm{Ph}) .{ }^{13} \mathrm{C} \mathrm{NMR}\left(75 \mathrm{MHz}, \mathrm{CDCl}_{3}\right): \delta_{\mathrm{C}} 22.3\left(\mathrm{CH}_{3}\right), 51.7(\mathrm{CH}), 52.6$ $\left(\mathrm{OCH}_{3}\right), 52.9\left(\mathrm{OCH}_{3}\right), 55.9(\mathrm{Ph} \underline{\mathrm{CH}}), 126.2,127.7,128.7,138.8$ (aromatic carbons), $167.5(\mathrm{C}=\mathrm{O})$, $168.8(\mathrm{C}=\mathrm{O}), 169.5(\mathrm{C}=\mathrm{O})$, analytical data are identical by comparisons with literature data. ${ }^{45}$

Dimethyl 2-(pivaloylaminoethyl)malonate (8d). White solid, $228 \mathrm{mg}$, yield $88 \%$. IR ( $v_{\max }, \mathrm{cm}^{-}$ $\left.{ }^{1}\right): 3428(\mathrm{~N}-\mathrm{H}), 1732(\mathrm{C}=\mathrm{O}), 1644(\mathrm{C}=\mathrm{O}), 1515(\mathrm{~N}-\mathrm{H}) .{ }^{1} \mathrm{H}$ NMR $\left(300 \mathrm{MHz}, \mathrm{CDCl}_{3}\right): \delta_{\mathrm{H}} 1.17$ $(9 \mathrm{H}, \mathrm{s}, t-\mathrm{Bu}), 1.26\left(3 \mathrm{H}, \mathrm{d}, J_{H H}=6.9 \mathrm{~Hz}, \mathrm{CH}_{3}\right), 3.62\left(1 \mathrm{H}, \mathrm{d}, J_{H H}=3.9 \mathrm{~Hz}, \mathrm{CH}\right), 3.71(3 \mathrm{H}, \mathrm{s}$, $\left.\mathrm{OCH}_{3}\right), 3.79\left(3 \mathrm{H}, \mathrm{s}, \mathrm{OCH}_{3}\right), 4.68\left(1 \mathrm{H}, \mathrm{ddq}, J^{1}{ }_{H H}=3.9 \mathrm{~Hz}, J_{H H}^{2}=6.9 \mathrm{~Hz}, J_{H H}^{3}=8.7 \mathrm{~Hz}, \mathrm{C} \underline{\mathrm{H}}-\right.$ $\left.\mathrm{CH}_{3}\right), 6.75\left(1 \mathrm{H}\right.$, br d, $\left.J_{H H}=8.7 \mathrm{~Hz}, \mathrm{NH}\right) .{ }^{13} \mathrm{C} \mathrm{NMR}\left(75 \mathrm{MHz}, \mathrm{CDCl}_{3}\right): \delta_{\mathrm{C}} 18.9\left(\mathrm{CH}_{3}\right), 27.3$ $\left(\mathrm{C}\left(\underline{\mathrm{CH}}_{3}\right)_{3}\right), 38.5\left(\underline{\mathrm{C}}\left(\mathrm{CH}_{3}\right)_{3}\right), 44.1\left(\mathrm{CH}_{3}\right), 52.4\left(\mathrm{OCH}_{3}\right), 52.6\left(\mathrm{OCH}_{3}\right), 55.1(\mathrm{CH}), 168.0(\mathrm{C}=\mathrm{O})$, $168.9(\mathrm{C}=\mathrm{O}), 177.6(\mathrm{C}=\mathrm{O})$. HR MS (EI) Calcd For $\left[\mathrm{M}^{+}\right] \mathrm{C}_{12} \mathrm{H}_{21} \mathrm{NO}_{5}$ 259.1420, Found: 259.1413. Dimethyl 2-(benzyloxycarbonylaminoethyl)malonate (8e). Colourless oil, $216 \mathrm{mg}$, yield 70\%. ${ }^{1} \mathrm{H}$ NMR $\left(300 \mathrm{MHz}, \mathrm{CDCl}_{3}\right): \delta_{\mathrm{H}} 1.29\left(3 \mathrm{H}, \mathrm{d}, J_{H H}=6.9 \mathrm{~Hz}, \mathrm{CH}_{3}\right), 3.63\left(1 \mathrm{H}, \mathrm{d}, J_{H H}=4.5 \mathrm{~Hz}, \mathrm{CH}\right)$, $3.70\left(3 \mathrm{H}, \mathrm{s}, \mathrm{OCH}_{3}\right), 3.75\left(3 \mathrm{H}, \mathrm{s}, \mathrm{OCH}_{3}\right), 4.43\left(1 \mathrm{H}, \mathrm{ddq}, J_{H H}^{1}=4.5 \mathrm{~Hz}, J_{H H}^{2}=6.9 \mathrm{~Hz}, J_{H H}^{3}=9.3\right.$ $\mathrm{Hz}, \mathrm{NH}-\mathrm{CH}), 5.08\left(2 \mathrm{H}, \mathrm{s}, \mathrm{PhCH}_{2}\right), 5.63\left(1 \mathrm{H}\right.$, br d, $\left.J_{H H}=9.3 \mathrm{~Hz}, \mathrm{NH}\right), 7.30-7.36(5 \mathrm{H}, \mathrm{m}, \mathrm{Ph})$, identical by comparisons with literature data. ${ }^{47}$

Dimethyl 2-(benzyloxycarbonylaminophenylmethyl)malonate (8f). Waxy solid, $297 \mathrm{mg}$, yield 80\%. ${ }^{1} \mathrm{H} \mathrm{NMR}\left(300 \mathrm{MHz}, \mathrm{CDCl}_{3}\right): \delta_{\mathrm{H}} 3.61\left(3 \mathrm{H}, \mathrm{s}, \mathrm{OCH}_{3}\right), 3.68\left(3 \mathrm{H}, \mathrm{s}, \mathrm{OCH}_{3}\right), 3.94(1 \mathrm{H}, \mathrm{d}$, $\left.J_{H H}=4.2 \mathrm{~Hz}, \mathrm{CH}\right), 5.06\left(1 \mathrm{H}, \mathrm{d}, J_{H H}=12.3 \mathrm{~Hz}, \mathrm{PhCH}_{2}\right), 5.12\left(1 \mathrm{H}, \mathrm{d}, J_{H H}=12.3 \mathrm{~Hz}, \mathrm{PhCH}_{2}\right), 5.56$ $\left(1 \mathrm{H}, \mathrm{dd}, J_{H H}^{1}=4.5 \mathrm{~Hz}, J_{H H}^{2}=9.3 \mathrm{~Hz}, \mathrm{CH}\right), 6.48\left(1 \mathrm{H}\right.$, br d, $\left.J_{H H}=9.3 \mathrm{~Hz}, \mathrm{NH}\right), 7.23-7.34(10 \mathrm{H}$, $\mathrm{m}, \mathrm{Ph})$, identical by comparisons with literature data. ${ }^{47}$

Ethyl 2-(acetylaminoethyl)acetoacetate $(\mathbf{8 g})$. Colourless oil, $183 \mathrm{mg}$, yield $85 \%$. IR ( $v_{\max }, \mathrm{cm}^{-}$ $\left.{ }^{1}\right): 3448(\mathrm{~N}-\mathrm{H}), 1710(\mathrm{C}=\mathrm{O}), 1680(\mathrm{C}=\mathrm{O}), 1512(\mathrm{~N}-\mathrm{H}) .{ }^{1} \mathrm{H} \mathrm{NMR}\left(300 \mathrm{MHz}, \mathrm{CDCl}_{3}\right): \delta_{\mathrm{H}} 1.28$ $\left(3 \mathrm{H}, \mathrm{t}, J_{H H}=6.9 \mathrm{~Hz}, \mathrm{OCH}_{2} \mathrm{CH}_{3}\right), 1.41\left(3 \mathrm{H}, \mathrm{s}, \mathrm{CH}_{3}\right), 1.95\left(3 \mathrm{H}, \mathrm{s}, \mathrm{CH}_{3} \mathrm{C}(\mathrm{O}) \mathrm{NH}\right), 2.20(3 \mathrm{H}, \mathrm{s}$, $\left.\mathrm{CH}_{3} \mathrm{C}=\mathrm{O}\right), 3.65\left(2 \mathrm{H}, \mathrm{d}, J_{H H}=6.6 \mathrm{~Hz}, \mathrm{CH}_{2}\right), 4.21\left(2 \mathrm{H}, \mathrm{q}, J_{H H}=6.9 \mathrm{~Hz}, \mathrm{OC}_{2} \mathrm{CH}_{3}\right), 6.11(1 \mathrm{H}$, br s, NH). ${ }^{13} \mathrm{C}$ NMR $\left(75 \mathrm{MHz}, \mathrm{CDCl}_{3}\right): \delta_{\mathrm{C}} 13.9\left(\mathrm{OCH}_{2} \mathrm{CH}_{3}\right), 18.0\left(\mathrm{CH}_{3}\right), 23.2\left(\mathrm{CH}_{3} \mathrm{C}(\mathrm{O}) \mathrm{NH}\right), 26.2$ 


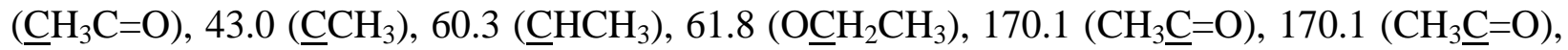
$171.8\left(\mathrm{CH}_{3} \underline{\mathrm{C}}(\mathrm{O}) \mathrm{NH}\right)$. HR MS (ESI) Calcd for $[\mathrm{M}+\mathrm{Na}]^{+} \mathrm{C}_{10} \mathrm{H}_{17} \mathrm{NO}_{4} \mathrm{Na}$ 238.1050, Found: 238.1061 .

Ethyl 2-(acetylaminomethyl)acetoacetate $(\mathbf{8 h})$. Colourless oil, $141 \mathrm{mg}$, yield $70 \%$. IR ( $v_{\max }$, $\left.\mathrm{cm}^{-1}\right)$ : $3448(\mathrm{~N}-\mathrm{H}), 1736(\mathrm{C}=\mathrm{O}), 1712(\mathrm{C}=\mathrm{O}), 1676(\mathrm{C}=\mathrm{O}), 1512(\mathrm{~N}-\mathrm{H}) .{ }^{1} \mathrm{H}$ NMR $(300 \mathrm{MHz}$, $\left.\mathrm{CDCl}_{3}\right): \delta_{\mathrm{H}} 1.29\left(3 \mathrm{H}, \mathrm{dd}, J_{H H}^{1}=J_{H H}^{2}=7.2 \mathrm{~Hz}, \mathrm{OCH}_{2} \mathrm{CH}_{3}\right), 1.94\left(3 \mathrm{H}, \mathrm{s}, \mathrm{CH}_{3} \mathrm{C}(\mathrm{O}) \mathrm{NH}\right), 2.30(3 \mathrm{H}$, $\left.\mathrm{s}, \mathrm{CH}_{3} \mathrm{C}=\mathrm{O}\right), 3.64-3.69\left(2 \mathrm{H}, \mathrm{m}, \mathrm{NHC}_{2} \mathrm{CH}\right), 3.87\left(1 \mathrm{H}, \mathrm{dd}, J^{1}{ }_{H H}=6.0 \mathrm{~Hz}, J^{2}{ }_{H H}=6.6 \mathrm{~Hz}\right.$, $\left.\mathrm{NHCH}_{2} \mathrm{C} \underline{\mathrm{H}}\right), 4.16-4.28\left(2 \mathrm{H}, \mathrm{m}, \mathrm{OCH}_{2} \mathrm{CH}_{3}\right), 6.12\left(1 \mathrm{H}\right.$, br s, NH). ${ }^{13} \mathrm{C} \mathrm{NMR}\left(75 \mathrm{MHz}, \mathrm{CDCl}_{3}\right): \delta_{\mathrm{C}}$ $14.0\left(\mathrm{OCH}_{2} \underline{\mathrm{CH}}_{3}\right), 23.1\left(\underline{\mathrm{CH}}_{3} \mathrm{C}(\mathrm{O}) \mathrm{NH}\right), 29.8\left(\underline{\mathrm{CH}}_{3} \mathrm{C}=\mathrm{O}\right), 37.2(\mathrm{CH}), 58.4\left(\underline{\mathrm{CHCH}}_{3}\right), 61.7$ $\left(\mathrm{OCH}_{2} \mathrm{CH}_{3}\right), 168.5\left(\mathrm{CH}_{3} \underline{\mathrm{C}}=\mathrm{O}\right), 168.5\left(\mathrm{CH}_{3} \underline{\mathrm{C}}=\mathrm{O}\right), 170.3\left(\mathrm{CH}_{3} \underline{\mathrm{C}}(\mathrm{O}) \mathrm{NH}\right)$. HR MS (EI) Calcd for $\left[\mathrm{M}^{+}\right] \mathrm{C}_{9} \mathrm{H}_{15} \mathrm{NO}_{4}$ 201.1001, Found: 201.0993.

\section{Amidoalkylation of dimethyl malonate with amidinium salt (5f) and guanidinium salt (5g) prepared in situ}

To a solution of 1-( $N$-pivaloylamino)ethyltriphenylphosphonium tetrafluoroborate $\mathbf{4 f}(0.191 \mathrm{~g}$, $0.4 \mathrm{mmol})$ in $\mathrm{MeCN}(0.8 \mathrm{~mL})$ a solution of DBN or TBD $(0.4 \mathrm{mmol})$ in $\mathrm{MeCN}(0.8 \mathrm{~mL})$ was added. After 1 minute a solution of dimethyl malonate $(0.423 \mathrm{~g}, 0.37 \mathrm{~mL}, 3.2 \mathrm{mmol})$ and DBN or TBD $(0.4 \mathrm{mmol})$ in $\mathrm{MeCN}(1.6 \mathrm{~mL})$ was added, and reaction was carried out as described above.

\section{Acknowledgements}

The financial help of the Ministry of Science and Higher Education of Poland (Grant No. N N204 165636) is gratefully acknowledged.

\section{References}

1. Fišera, L. N-Acylimines, In Science of Synthesis Houben-Weyl Methods of Molecular Transformations, Thieme Chemistry: Stuttgart, 2004; Vol. 27, p 349.

2. Malassa, I.; Matthies, D. Chemiker-Zeitung 1987, 111 (6), 181.

3. Malassa, I.; Matthies, D. Chemiker-Zeitung 1987, 111 (9), 253.

4. Zhang, L.; Wei, Ch.; Li, Ch.-J. Tetrahedron Lett. 2002, 43, 5731.

5. Foresti, E.; Palmieri, G.; Petrini, M.; Profeta, R. Org. Biomol. Chem. 2003, 1, 4275.

6. Zaugg, H. E. Synthesis 1970, 49; ibid. Synthesis 1984, 85; ibid. Synthesis 1984, 181.

7. Speckamp, W. N.; Hiemstra, H. Tetrahedron 1985, 41, 4367.

8. Speckamp, W. N.; Moolenaar, M. J. Tetrahedron 2000, 56, 3817.

9. Katritzky, A. R.; Manju, K.; Singh, S. K.; Meher, N. K. Tetrahedron 2005, 61, 2555.

10. Katritzky, A. R.; Lan, X.; Yang, J. Z.; Denisko, O. V. Chem. Rev. 1998, 98, 409. 
11. Petrini, M. Chem. Rev. 2005, 105, 3949.

12. Zhang, L.; Wei, Ch.; Li, Ch.-J. Tetrahedron Lett. 2002, 43, 5731.

13. Mazurkiewicz, R.; Październiok-Holewa, A.; Grymel, M. Tetrahedron Lett. 2008, 49, 1801.

14. Mazurkiewicz, R.; Październiok-Holewa, A.; Grymel, M. Phosphorus, Sulfur and Silicon 2009, 184, 1017.

15. Mazurkiewicz, R.; Październiok-Holewa, A.; Orlińska, B.; Stecko, S. Tetrahedron Lett. 2009, 50, 4606.

16. Mazurkiewicz, R.; Adamek, J.; Październiok-Holewa, A.; Zielińska, K.; Simka, W.; Gajos, A.; Szymura, K. J. Org. Chem. DOI: 10.1021/jo202534u; 16 Jan. 2012.

17. Adamek, J.; Mrowiec-Białoń, J.; Październiok-Holewa, A.; Mazurkiewicz, R. Thermochimica Acta 2011, 512, 22.

18. Mazurkiewicz, R.; Adamek, J. Październiok-Holewa, A.; Gorewoda, T.; Simka, W. RP Pat. Appl. P.390177, 2010.

19. Mazurkiewicz, R.; Adamek, J. Październiok-Holewa, A.; Zielińska, K.; Simka, W. RP Pat. Appl. P.396661, 2011.

20. Mazurkiewicz, R.; Październiok-Holewa, A.; Kononienko, A. Phosphorus, Sulfur and Silicon 2010, 185, 1986.

21. Październiok-Holewa, A. Ph.D. Thesis, Silesian University of Technology, Gliwice, 2009.

22. Linstead, R. P.,; Shephard, B. R.; Weedon, B. C. L. J. Chem. Soc. 1951, 2854.

23. Horikawa, H.; Iwasaki, T.; Matsumoto, K.; Miyoshi, M. Tetrahedron Lett. 1976, 17, 191.

24. Iwasaki, T.; Horikawa, H.; Matsumoto, K.; Miyoshi, M. J. Org. Chem. 1977, 42, 2419.

25. Iwasaki, T.; Horikawa, H.; Matsumoto, K.; Miyoshi, M. J. Org. Chem. 1979, 44, 1552.

26. Iwasaki, T.; Horikawa, H.; Matsumoto, K. Bull. Soc. Chem. Jpn 1979, 52, 826.

27. Lund, H.; Hammerlich, O. Organic Electrochemistry, Marcel Dekker, New York, 2001.

28. Tajima T.; Kurihara, H.; Fuchigami, T. J. Am. Chem. Soc. 2007, 129, 6680.

29. Matsumura, Y.; Tanaka, T.; Wanyoike, G.N.; Maki, T.; Onomura, O. J. Electroanal. Chem. 2001, 507, 71.

30. Matsumura, Y.; Wanyoike, G.N.; Onomura, O.; Maki, T. Electrochimica Acta 2003, 48, 2957.

31. Wanyoike, G.N.; Onomura, O.; Maki, T.; Matsumura, Y. Organic Lett. 2002, 11, 1875.

32. Onomura, O. Yakugaku Zasshi 2002, 122, 983.

33. Zietlow, A.; Steckhan, E. J. Org. Chem. 1994, 59, 5658.

34. Kardasis, G.; Brungs, P.; Steckhan, E. Tetrahedron 1998, 54, 3471.

35. Ishikawa, T.; Kumamoto, T. Amidines in Organic Synthesis in: Superbases for Organic Synthesis, J. Wiley \& Sons, Ltd., Chichester, 2009, 51.

36. Kers, A.; Kers, I.; Stawiński, J. J. Chem. Soc. Perkin Trans. 2, 1999, 2071.

37. Kers, A.; Stawiński, J. Tetrahedron 1997, 53, 12691.

38. Tolsticova, L. L.; Shainyan, B. A. Russian Journal of Organic Chemistry 2006, 42, 1068.

39. Archibald, S. C.; Fleming, I. J. Chem. Soc. Perkin Trans. 1 1993, 751.

40. Arnold, L.D.; Drover, J.C.G.; Vederas, J.C. J. Am. Chem. Soc. 1987, 109, 4649. 
41. Matsubara, R.; Kawai, N.; Kobayashi, S. Angew. Chem. Int. Ed. 2006, 45, 3814.

42. Mansilla, J.; Saà, J. M. Molecules 2010, 15, 709.

43. Mecozzi, T.; Petrini, M. Synlett 2000, 1, 73.

44. Lukyanov, S. M. in The Chemistry of Enamines, Chemistry of Functional Groups; Rappoport, Z., Ed.; Wiley, 1994; p 1441.

45. Hellmann, H.; Aichinger, G.; Wiedemann, H-P. Liebigs Ann. Chem. 1959, 626, 35.

46. Xu, J.; Fu, Y.; Xiao, B.; Gong, T.; Guo, Q. Tetrahedron Lett. 2010, 51, 5476.

47. Marianacci, O.; Micheletti, G.; Bernardi, L.; Fini, F.; Fochi, M.; Pettersen, D.; Sgarzani, V.; Ricci, A. Chem. Eur. J. 2007, 13, 8338. 